Egyptian Journal of Rabbit Science, 29 (1): 149-167(2019)

\title{
INFLUENCE OF REPLACEMENT EGYPTIAN TREE WILLOW (Salix Safsaf) (LEAVES AND SMALL STEMS) WITH BERSEEM HAY ON SOME REPRODUCTIVE OF DOE RABBITS.
}

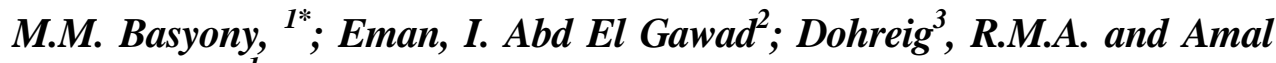 \\ Abd El-Salam \\ ${ }^{I}$ Department of Poultry Nutrition Research, Animal Production Research Institute, \\ Agricultural Research Center, Giza, Egypt; \\ ${ }^{2}$ Department of Sheep and Goat Research, Animal Production Research Institute, Agricultural \\ Research Center, Giza, Egypt; \\ ${ }^{3}$ Department of A.I Research Institute, Agricultural Research Center, Giza, Egypt. \\ *Corresponding author: E-mail: Address: mohamed000basyony@yahoo.com.
}

The present study aimed to investigate the effects of replacing Berseem hay by different levels of Salix Safsaf hay on some reproductive and productive traits of doe rabbits and their offspring's, during the pregnancy and lactation periods. Thirty six New Zealand White (NZW) doe rabbits about 6-7 months old (2.990 - $3.150 \mathrm{~kg})$ were randomly allotted between four experimental groups (9 rabbits in each treatment group).The control group was fed a basal diet, which including $34 \mathrm{Kg} / 100 \mathrm{Kg}$ of Berseem hay(T1); the experimental groups received the basal diet replacement with 10.75, 17 and $23.25 \mathrm{Kg} / 100$ $\mathrm{Kg}$ Salix Safsaf hay of (34 Kg/l00 Kg) Berseem hay diets (T2, T3 and T4), respectively).The experimental period lasted three cycles.

Body weights of does at first week of lactation and at weaning day were $(P=0.01$ and 0.004$)$ higher in all experimental groupsas compared to control group respectively, while the response of does body weights at initial weight, before and after parturition day were insignificantly affected. As well as gestation length (days) was not significant affected by the replacement of tree willow leaves.

Does rabbits in groupT2 had $(P=0.005)$ higher total feed intake during lactation period in compared with the T1, T3 and T4 group .But, during pregnancy total feed intake was insignificantly affected by replacing Berseem hay by different levels of Salix Safsaf hay.

During lactation period weekly and total milk yield were different in treated groups. The improvement of milk yield at $2^{\text {nd }}, 3^{\text {rd }}$ and $4^{\text {th }}$ of lactation were $(P=0.041,0.005$ and 0.05$)$ increased in group $T 2$ compared to the control group and the other experimental groups.

Average litter weight at weaning and weight gain $(P=0.0015$ and 0.01) increased for groups T2 and T3 compared to groups T1 and T4, 
respectively. The same trends were observed in pre- weaning survival rate (\%) from birth to weaning age fed diets including 25 and 50\% Salix Safsaf. Replacing Berseem hay in does rabbit diets by Salix Safsaf hay reduced the feeding cost of experimental rabbits.

Keywords: Salix Safsaf, does rabbit, reproductive performance, economic efficiency.

Egyptian villages have an ancient thought that rabbit is a productive and fast growing animal that has the possible to produce a substantial amount of meat in a relatively short time. Rabbits are also able to grow and reproduce well from inexpensive forages, agricultural by-product, as well as from commercial premixed diets. Therefore, rabbits can be raised in small -scale. This small-scale system could help numerous household to have meat and also a small but significant cash income source. In the other wise, rabbit diets, roughage sources are included as well, accounting for $35 \%$ to $40 \%$ of diet volume. Among these sources is berseem hay, which is a dietary source of high cost (Abdel-Kafy et al., 2017). In these circumstances, it is important to search non-traditional feeds in animal feeding having low cost and to raise the product and decreasing the marketing price of animal products. The list of what ingredients can be incorporated into rabbit feed is enormous and growing continuously (Ibrahim, 2000).

The Egyptian willow (Salix Safsaf) is a small tree growing in Egypt since pre-historic times. It is generally found in wet ground such as along water-ways. White willow which is also known as the salicin willow has been used for its health benefits for thousands of years (Saller et al., 2008). Its branches, being long, thin and pliant, Leaves, seeds, and other parts of the plant were used in medicine. In the Hearst medical papyrus seeds are recommended for cooling the vessels, and for cooling a bone after it has been set (Lise Manniche, 1989). The total $\mathrm{N}$ and ME content of willow fodder are about $26.3 \mathrm{~g}$ and 10.5 MJ per kg DM, respectively (ThiMui et al., 2005). Willow is moderately digestible and highly palatable for livestock and it is a source of minerals for grazing livestock, including calcium, magnesium, potassium and zinc (Guevara-Escobar, 1999). Willow species synthesize low molecular phenolic glycosides, such as salicin (35 g/kg DM) and/or condensed tannin (CT, $38 \mathrm{~g} / \mathrm{kg} \mathrm{DM}$ ) (Pitta et al., 2007). Salicin and salicortin are the primary salicylates found in white willow (Salix Safsaf). They are metabolized by intestinal flora to saligenin Julkunen-Tiitto and Meier (1992), absorbed into the blood stream, and metabolized by the liver to salicylic acid; excretion is primarily through renal (Bissettet, 1994 and Fotsch et al., 1989). 
Therefore, this study aimed to compare more correctly the single and mixed effects on reproductive performance of does rabbits and their offspring's during the pregnancy and lactation fed on different levels of stem and leave Salix Safsaf hay as partial replacement of Berseem hay.

\section{MATERIALS AND METHODS}

Experimental work was carried out at El Nobaria Animal Production Research Station, Behera Governorate, Animal Production Research Institute, Egypt. It was started in September, 2017 and lasted for 16 weeks.

A total of thirty six New Zealand White (NZW) does at maturation age (6 - 7 month), weighing $2.990-3.150 \mathrm{~kg}$ was equally divided into 4 experimental treatments 9 does in each treatment group. The basal diet was formulated and pelleted to cover the nutrient requirements of rabbits according to De Blas and Wiseman (1998) as shown in (Table 1).

The Egyptian willow trees plants variety (salix safsaf) was used for this study. The small stems and leaves part was collected directly in the field, in the region of Nile River in Nobaria, El Behera Governorate Egypt. The collected material was chopped into pieces smaller than $2 \mathrm{~cm}$, using a forage chopper.

The resulting material was then spread over a cement floor, turned over twice a day during three days until complete drying, resulting in hay. It was later baled and stored in a dry and ventilated environment until the time of use, when it was ground for inclusion in the feed.

The experimental groups were classified to four groups as follow: Treatment 1 basal diet contained $34 \mathrm{Kg} / 100 \mathrm{Kg}$ Berseem hay and served as control diet (T1).Treatment 2 basal diet contained 10.75 Salix Safsaf +23.25 Berseem hay $\mathrm{Kg} / 100 \mathrm{Kg}$ (T2).Treatment 3 basal diet contained 17 Salix Safsaf + 17 Berseem hay $\mathrm{Kg} / 100 \mathrm{Kg}$ (T3). Treatment 4 basal diet contained 23.75 Salix safsaf + 10.75 Berseem hay Kg/100Kg (T4).

Feed and water were provided ad libitum, except for does with reproductive problems and outside the lactation period, which received only $120 \mathrm{~g}$ daily to avoid overweight. All animals were kept under the same environmental and managerial conditions.

The male: female ration was 1:5. Females were serviced in the morning, with repeated servicing in the late afternoon, always with the same buck as before. Ten days after kindling, does were serviced again, by taking the female to the male's cage, thereby starting a new reproductive cycle. Whenever the doe did not accept the buck, mating was forced. Females were examined ventrally 10 days after service, and those 
Table (1): Composition $(\mathrm{Kg} / 100 \mathrm{Kg})$ of the experimental diets:

\begin{tabular}{|c|c|c|c|c|}
\hline \multirow[t]{2}{*}{ Ingredients $^{* * *}$} & \multicolumn{4}{|c|}{ Experimental diets } \\
\hline & T1 & T2 & T3 & T4 \\
\hline Berseem hay & 34 & 23.25 & 17 & 10.75 \\
\hline Salix safsaf & - & 10.75 & 17 & 23.25 \\
\hline Barley grains & 15 & 15 & 15 & 15 \\
\hline Plant Concentrate & 11.64 & 11.64 & 11.64 & 11.64 \\
\hline Yellow corn & 10 & 10 & 10 & 10 \\
\hline Wheat bran & 14 & 14 & 14 & 14 \\
\hline Soybean meal $44 \% \mathrm{CP}$ & 10 & 10 & 10 & 10 \\
\hline Molasses & 3 & 3 & 3 & 3 \\
\hline Limestone & 1.1 & 1.1 & 1.1 & 1.1 \\
\hline Di-Calcum phosphate & 0.6 & 0.6 & 0.6 & 0.6 \\
\hline Sodium chloride & 0.3 & 0.3 & 0.3 & 0.3 \\
\hline Vit-min premix ${ }^{*}$ & 0.3 & 0.3 & 0.3 & 0.3 \\
\hline Lysine & 0.02 & 0.02 & 0.02 & 0.02 \\
\hline DL-Methionine & 0.04 & 0.04 & 0.04 & 0.04 \\
\hline Total & 100 & 100 & 100 & 100 \\
\hline Price & 4900 & 4700 & 4500 & 4300 \\
\hline
\end{tabular}

**Ingredients prices (L.E. per ton) at 2018 were: 3450 barley; 4550 yellow corn; 3050 berseem hay (12\%) ; 3100 wheat bran ; 8500 plant Concentrate; 7850 soybean meal (44\%) ; 250 limestone ; 25000 premix ; 550000 DL-methionine ; 21000 DL-lysine; 10500 dicalcuim phosphate ; 250 Egyptian Salix safsaf; 500 salt; 1800 cane molasses. - Adding 100 L.E. /ton for pelleting.

* Vit. and Min. mixture: Each kilogram of Vit. and Min. mixture contains: 2000.000 IU Vit. A, 150.000 IU Vita. D, 8.33 g Vit. E, 0.33 g Vit. K, 0.33 g Vit. B1, 1.0 g Vit. B2, 0.33g Vit. B6, $8.33 \mathrm{~g}$ Vit.B 5, $1.7 \mathrm{mg}$ Vit. B 1,2 $3.33 \mathrm{~g}$ Pantothenic acid, $33 \mathrm{mg}$ Biotin, 0.83g Folic acid, 200 g Choline chloride, $11.7 \mathrm{~g} \mathrm{Zn}, 12.5 \mathrm{~g} \mathrm{Fe}, 16.6 \mathrm{mg} \mathrm{Se}, 16.6 \mathrm{mg} \mathrm{Co}, 66.7 \mathrm{~g} \mathrm{Mg}$ and $5 \mathrm{~g} \mathrm{Mn}$..

$\mathrm{T} 1=$ basal diet contained $34 \mathrm{Kg} / 100 \mathrm{Kg}$ Berseem hay.

T2=basal diet contained 10.75 Salix Safsaf +23.25 Berseem hay Kg/100 Kg.

T3=basal diet contained 17 Salix Safsaf + 17 Berseem hay Kg/100 Kg.

T4 basal diet contained 23.25 Salix Safsaf + 10.75 Berseem hay Kg/100Kg.

that failed were serviced again. The experimental rabbits were allotted in a windowed house. Flat desk cages $(60 \times 55 \times 40 \mathrm{~cm})$ provided with galvanized Nestle lettings for does, feeders and drinker nipples. All kindling kits were remained in the nests with their dams for suckling from birth up to weaning at 28 days of age. For analysis of reproduction-related traits, the following were evaluated: doe weight at service, before parturition day, after parturition day, at first week of lactation and at weaning day; total feed intake during pregnancy, lactation period and within each cycle by does; number and weight of kits born and weaned per doe during the three cycles; litter body weight at weaning per cycle; total number and total body weight of kits at kindling and weaning during the three reproductive cycles. For the weight and number of 
kits at kindling, the average weight and number of live-born + stillborn animals were considered. Milk yield was estimated day after day by the difference in doe weight before and after suckling that occurred once every test day. The decrease in mother weight was considered as the milk yield. Litter size, litter weight $(\mathrm{g})$ at birth and weaning were recorded as mass product/doe; pre-weaning survival rate $(\%)$ recorded too.

\section{Chemical composition of feed:}

Samples of each treatments feed Salix safsaf and berseem hay were analyzed for dry matter (DM), crude protein (CP), ether extract (EE), crude fiber (CF), and ash according to the classical (AOAC, 1996) methods. The nutritive value of the experimental diets as DCP and TDN value were calculated according to Cheeke, et al. (2013). Neutral detergent fiber (NDF), acid detergent fiber (ADF) and acid detergent lignin (ADL) were also determined in the experimental rations according to Goering and Van Soest (1970).

Hemicellulose was calculated as the difference between NDF and ADF, while cellulose was calculated as the difference between ADF and ADL. Gross energy (kilo calories per kilogram DM) was calculated according to Blaxter (1968), where, each $\mathrm{g}$ of crude protein $(\mathrm{CP})=5.65 \mathrm{kcal}$, each $\mathrm{g}$ of ether extract $(\mathrm{EE})=9.40 \mathrm{kcal}$ and each $\mathrm{g}$ crude fiber $(\mathrm{CF})$ and nitrogen- free extract $(\mathrm{NFE})=4.15 \mathrm{kcal}$. Digestible energy $(\mathrm{DE})$ was calculated according to Fekete and Gippert (1986) using the following equation: DE (kcal/ kg DM) = 4253-32.6 (CF \%) - 144.4 (total ash). Non fibrous carbohydrates (NFC) were calculated according to Calsamiglia et al. (1995) using the following equation:

$$
\mathrm{NFC}=100-\{\mathrm{CP}+\mathrm{EE}+\mathrm{Ash}+\mathrm{NDF}\} \text {. }
$$

The CT of Salix Safsaf was determined according to Makkar (2003), salicin and phenolic compounds were determined using the high-performance liquid chromatographic using the procedure of Meier et al. (1988).

\section{Relative economic efficiency:}

The relative economic efficiency of the experimental diets for the cost of feed required for producing total $\mathrm{kg}$ of body weight gain were calculated. The cost of the experimental diets was calculated according to the price of different ingredients prevailing in local market, as well as, the price of testing materials at the time of experimentation. Economic efficiency was calculated as a ratio between the return of weight gain and the cost of consumed feed.

\section{Statistical Analysis:}

The experimental design was completely randomized using the General Linear Means of SAS (2001). Measured parameters were analyzed using the following statistical model: 


$$
Y i j=\mu+d i+\varepsilon i j .
$$

Where yij is the value measured, $\mu$ is the overall mean effect, di is the ith diet effect and $\varepsilon i j$ is the random error associated with the jth rabbits assigned to the ith diet. Significant differences of $(\mathrm{P}<0.05)$ among means were determined using Duncan's Multiple Range Test (Duncan, 1955).

\section{RESULTS AND DISCUSSION}

Chemical analysis and cell wall constituents of the tested materials and the experimental diets are presented in Table 2. The chemical composition of Salix safsaf as crude protein, ether extract, ash, gross energy, hemicelluloses, cellulose, dry matter, organic matter, crude fiber, nitrogen-free extract, digestible energy (Kcal/kg DM), non fibrous carbohydrates, acid detergent lignin, acid detergent fiber and neutral detergent fiber contents were in the same range for both Salix Safsaf (leaves and stems) and Berseem hay.

Muklada et al (2018) reported that willow fodder composed of $45 \%$ leaves and 55\% stems, on a DM basis; the weighted content of CP, ME, NDF, $\mathrm{Ca}$, and $\mathrm{P}$ were (on a DM basis): $13.6 \%, 1.8 \mathrm{Mcal}, 44.9 \%, 1.1 \%$, and $0.2 \%$, respectively. Lead, nickel and cadmium were found below the detection threshold in willow fodder and the concentrations of metals did not exceed the recommended ranges in feed. As well as, Salix safsaf hay contained an adequate amount of DM, OM, CP, NDF, ADF and DE, which support moderate growth of livestock (McWilliam 2004).

Jo Smith et al (2014) reported that leaves + stem of willow tree contained 167 $\mathrm{g} / \mathrm{kg}$ crude protein on dry matter (DM), while the Neutral detergent fiber, Acid detergent fiber and lignin concentration were 573,410 and $184 \mathrm{~g} / \mathrm{Kg}$ dry matter, respectively.

However, the organic matter digestibility determined by in vitro pepsincellulase method was low ( 0.405 for leaf + stem $)$ and it might be suitable for other animal groups with lower energy requirements. No condensed tannins (CT) or salicin was detected in Berseem hay but Salix Safsaf had a relatively moderate (CT) and high salicin contents, (Table 2). The stems and leaves of Salix safsaf contained substantial concentrations of secondary metabolites, including lignin, CT, salicin and other phenolic compounds. In this connect Muklada et al (2018) they analyzed Leaf and stem of willow tree and found it contained condensed tannins (6.9 and 4.5\%), respectively, while, it contains total phenolic compound (9.4 and 4.8\%). However, McWilliam et al (2005) said that willow contained high concentrations of condensed tannin (CT; 52 $\mathrm{g} / \mathrm{kg})$ and total phenolic glycosides $(34 \mathrm{~g} / \mathrm{kg}$. 
EFFECT OF REPLACEMENT Salix SafsafWITH BERSEEM HAY ON RABBITS 155

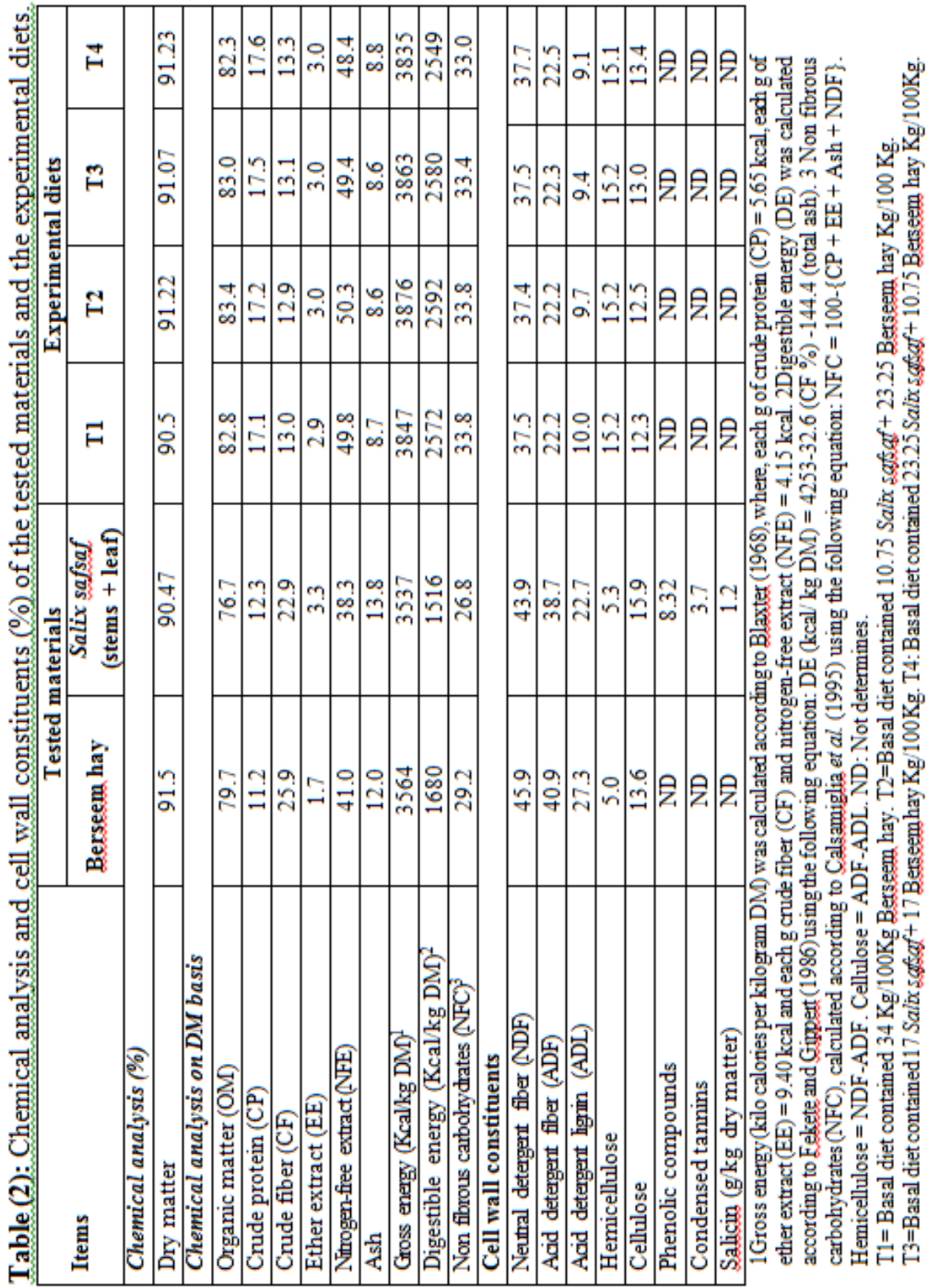


The experimental diets were iso caloric and iso nitrogenous. Protein contents for the four tested rations $\left(\mathrm{T}_{1}-\mathrm{T}_{4}\right)$ ranged from 17.1 to $17.6 \%$, the digestible energy values ranged from 2549 to $2592(\mathrm{kcal} / \mathrm{kg} \mathrm{DM})$ for all diets. All parameters determined of chemical analysis were similar for the different experimental diets regardless the phytochemicals content of used Salix safsaf.

\section{Body weight of does}

Body weights of doe rabbits as affected by replacement Salix Safsaf with berseem hay were displayed in Table 2. Initial doe weight of the animals, ranging between 2990 and $3150 \mathrm{~g}$. Results show that average doe body weight during pregnancy and lactation not significantly affected by replacement Salix Safsaf with berseem hay, except for lactation day and at weaning day, respectively. Improved body weight $(\mathrm{P}=0.01$ and 0.004$)$ at first week of lactation and at weaning day were detected due to the dietary stems and leaves of Salix Safsaf as compared with control group, respectively. This improvement back to the increase feed intake in T2, T3 and T4 as compared with T1 (control), as well as heavy does were heavier as a consequence of a higher feed intake or a higher growth potential, but that over fattening had not occurred (Rommers et al 2002).

Body weight after parturition (day) followed a downward trend when compared with the initial body weight of all the experimental treatment. This reduction in body weight back to rabbit does are susceptible to a severe energy deficit during first lactation (Xiccato, 1996), resulting in decreased reproductive performance. Average gestation length for all the animals also, falls within 29.7-30.1days with no significant difference across the treatments. The results are in agreement with the findings of (Saha et al., 2013).

\section{Total feed intake of does}

In this concern, Basyony et al (2018) found that grower rabbits fed diets including different levels 25, 50 and $75 \%$ of stems and leaves of Salix safsaf hay with berseem hay feed intake of (DM, CP and DE) was insignificant $(\mathrm{P}>$ 0.05) decreased when compared with control diets. Meanwhile, Muklada et al (2018) said that goats fed on the willow fodder consumed less DM than the goats fed on clover hay (1760 and $2100 \mathrm{~g} / \mathrm{d},(\mathrm{P}<0.01)$, respectively). However, increased feed intake with low Salix Safsaf substitution may have been due to positive impacts of low dose of plant secondary metabolites on cecal fermentation, whereas the high Salix Safsaf dose high plant secondary metabolites substitution with antimicrobial activity decreased microbial activity and diet ferment ability, which negatively affected dry matter intake (Jiménez-Peralta et al., 2011; Salem et al., 2011). Replacement of low doses of salix safsaf likely encouraged some cecal bacterial species to metabolize 
EFFECT OFREPLACEMENT Salix SafsafWITH BERSEEM HAY ON RABBITS 157

phenolic compounds (Chen et al., 1988; Salem et al., 2010), and may act as catalysts for fiber digestion by increasing access of fibrolytic bacteria to cell wall polysaccharides in the diet. This action will lead to increased rates of disappearance in the cecum, with increased rates of passage and feed intake as a result (Conrad, 1966). Also, differences in feed intake observed by various researchers could be linked to differences in feed types, feed ingredients used, litter size, as well as the stage of maturity of forages used in feeding the rabbit does. Rabbit does moderate their nutrient intake to provide for their fetuses and for mammary glands development required during lactation (Iyeghe Erakpotobor et al., 2006). Another aspect related to the lower intake of the half-simplified diet could be the presence of polyphenols in the Salix Safsaf leaves (8.32\%), which may affect the palatability of the diet especially during the pregnancy periods.

\section{Milk yields of does}

Milk production $(\mathrm{g})$ of does during lactation periods were significantly affected by substitution Salix Safsaf to berseem hay as compared to the control (Table 3). Milk production (g) of does during lactation periods were significantly affected does rabbit fed diet $\mathrm{T} 2$ constantly had a higher caused milk yield in comparison with T1, T3 and T4. Also, doe rabbits feed in T2 caused an increase significantly $(\mathrm{P}=0.05)$ milk yield, during lactation periods at $2^{\text {nd }}, 3^{\text {rd }}$ and $4^{\text {th }}$ week when compared to control group. This could be due to that synergistic effect between Salix Safsaf and berseem to improved secretions metabolic hormones which altered in lactating does to favor mobilization of body reserves to support milk production.

Besides, Salem et al (2016) showed that supplementation of 0, 150 and $300 \mathrm{~mL}$ of Salix babylonica (SB) extract mixed into the cow diets cows caused increased $(\mathrm{P} \leq 0.05)$ milk production. Another important factor affecting milk output is the increased litter size. During the lactation, milk output is higher when the litter size is larger (McNitt and Lukefahr, 1990). As well as increasing food consumption during lactation period may be due to the increase of both doe body weight and milk production during the lactation as shown in (Table 3). Through that study we conclude that body weight of dams had a positive effect on the milk production.

The obtained positive correlation between milk yield and dam body weight may be attributed to the increase of the mammary gland size by increasing the dam body weight hence the increase in milk production. The present results were agreed with that obtained by MacNitt and Lukefahr (1990) and Yamani et al., (1992) who reported a significant correlation between milk yield and doe weight at kindling. 
Table 3: Effect of dietary treatments on live body weight and feed intake of does during pregnancy and lactation periods.

\begin{tabular}{|c|c|c|c|c|c|c|}
\hline \multirow{2}{*}{ Items } & \multicolumn{4}{|c|}{ Experimental treatment } & \multirow{2}{*}{ SEM } & \multirow{2}{*}{$\begin{array}{c}P- \\
\text { value }\end{array}$} \\
\hline & T1 & $\mathbf{T 2}$ & T3 & T4 & & \\
\hline \multicolumn{7}{|l|}{ Body weight(g): } \\
\hline Initial weight of doe & 2990 & 3070 & 3150 & 3025 & 108.47 & 0.469 \\
\hline Before parturition day & 3140 & 3300 & 3325 & 3295 & 61.01 & 0.25 \\
\hline After parturition day & 2890 & 2905 & 2850 & 2800 & 55.69 & 0.321 \\
\hline At first week of & $2800^{\mathrm{b}}$ & $3000^{\mathrm{a}}$ & $3071^{\mathrm{a}}$ & $3000^{\mathrm{a}}$ & 57.81 & 0.01 \\
\hline lactation & $2915^{\mathrm{b}}$ & $3100^{\mathrm{a}}$ & $3130^{\mathrm{a}}$ & $3075^{\mathrm{a}}$ & 86.47 & 0.004 \\
\hline $\begin{array}{l}\text { At weaning day } \\
\text { Gestation length (days) }\end{array}$ & 30.1 & 30.1 & 29.7 & 30 & 0.97 & 0.224 \\
\hline \multicolumn{7}{|l|}{ Total feed intake } \\
\hline During pregnancy & 3775 & 3710 & 3700 & 3690 & 99.91 & 0.55 \\
\hline During Lactation & $4090^{c}$ & $4630^{\mathrm{a}}$ & $4510^{\mathrm{ab}}$ & $4210^{b}$ & 130.24 & 0.005 \\
\hline \multicolumn{7}{|l|}{ Mill yield (g/week): } \\
\hline $1^{\mathrm{st}}$ & 81.22 & 82.17 & 83.11 & 80.36 & 8.01 & 0.215 \\
\hline $2^{\text {nd }}$ & $99.11^{\mathrm{b}}$ & $112.65^{\mathrm{a}}$ & $106.04^{\mathrm{ab}}$ & $89.69^{c}$ & 21.01 & 0.041 \\
\hline $3^{\text {rd }}$ & $119.40^{\mathrm{b}}$ & $135.30^{\mathrm{a}}$ & $123.96^{\mathrm{ab}}$ & $97.93^{\mathrm{c}}$ & 13.10 & 0.001 \\
\hline $4^{\text {th }}$ & $91.48^{\mathrm{b}}$ & $115.02^{\mathrm{a}}$ & $110.36^{\mathrm{ab}}$ & $79.23^{\mathrm{c}}$ & 16.7 & 0.05 \\
\hline
\end{tabular}

a- c, Means within a row not sharing similar superscripts are significantly different.

$\mathrm{T} 1=$ basal diet contained $34 \mathrm{Kg} / 100 \mathrm{Kg}$ Berseem hay.

$\mathrm{T} 2=$ basal diet contained 10.75 Salix safsaf +23.25 Berseem hay $\mathrm{Kg} / 100 \mathrm{Kg}$.

T3=basal diet contained 17 Salix Safsaf +17 Berseem hay $\mathrm{Kg} / 100 \mathrm{Kg}$.

T4 basal diet contained 23.25 Salix Safsaf + 10.75 Berseem hay $\mathrm{Kg} / 100 \mathrm{Kg}$.

Other studies Lukefahr et al (1983) and Ekambaram et al (2006) found no significant relationship between milk yield and doe weight at kindling. Does rabbits fed on the $75 \%$ SalixSsafsaf instead of berseem hay diet ingested less feed. This lower amount was insufficient to provide the necessary nutrients to maintain the females while gestating and producing milk. Consequently, there was a higher kit mortality rate $(\mathrm{P} \geq 0.05)$ and lower weight at kindling compared with kits from does fed the reference feed (Table 4). Almost no published reports are available in the literature on the effect of Salix Safsaf inclusion in diet of rabbits on milk production; therefore, the present results could not be compared. In parallel to our results Etima and Oguike (2014) found that doe rabbits fed mixed forages (Centrosema pubescens, Ipomea batatas leaves and Panicum maximum) plus concentrate diet (500 gram of forage per kilogram body weight) until after kindling, made a milk yield significantly $(\mathrm{P}<0.05)$ higher than control rabbits fed on Aspilia Africana alone plus concentrated diet. These findings particularly for T2 
EFFECT OFREPLACEMENT Salix SafsafWITH BERSEEM HAY ON RABBITS 159

showed that maximum milk production could be obtained using forages that have both lactopoietic and lactogenic properties such as Salix Safsaf.

\section{Litter performances of does}

Performance and survival rate (\%) of litters as affected by studied replacement Salix Safsaf to berseem hay are displayed in Table 4. Results show that litter size at birth and at weaning was not significantly affected by studied incorporation Salix Safsaf instead of berseem hay.

In this connect, Alemede et al.(2014), who reported that litter size at weaning of (5.2) in a study to evaluate the effects of feeding does with varying levels of Moringa leaves meal on reproduction. Also, improved litter weight $(\mathrm{P}=0.04)$ at weaning was detected due to the Salix Safsaf tried, especially feeding diets in T2 and T3. Thus, litter weight at this time would expect to be a useful index for lactation performance (Knight et al., 1989). Also, the increase in their weight gain may be due to the increase in milk yield (Table $3)$.

Average litter weight gain followed the same pattern as the litter weight at weaning with T2 $(25 \%)$ and T3 (50\%) dietary treatments groups recording the highest litter weight gain. However, average litter weight gain in group of $\mathrm{T} 4(75 \%)$ was better than control group $\mathrm{T} 1$.

Table 4: Effect of dietary treatments on performance of Litter at birth and weaning of does during the three reproductive cycles.

\begin{tabular}{|l|c|c|c|c|c|c|}
\hline \multirow{2}{*}{$\begin{array}{l}\text { Treatment } \\
\text { groups }\end{array}$} & \multicolumn{2}{|c|}{$\begin{array}{c}\text { Litter } \\
\text { size }\end{array}$} & \multicolumn{2}{c|}{$\begin{array}{c}\text { Average litter } \\
\text { weight (g) }\end{array}$} & $\begin{array}{c}\text { Average } \\
\text { litter } \\
\text { Weight } \\
\text { gain } \\
\text { (g) }\end{array}$ & $\begin{array}{c}\text { Pre- } \\
\text { weaning } \\
\text { survival } \\
\text { rate, (\%) }\end{array}$ \\
\hline T1 & Weaning & Birth & Weaning & & \\
\hline T2 & 7.31 & 6.83 & 296 & $2879^{\mathrm{b}}$ & $2583^{\mathrm{c}}$ & $94.6^{\mathrm{b}}$ \\
\hline T3 & 7.11 & 7.05 & 313 & $3342^{\mathrm{a}}$ & $3029^{\mathrm{a}}$ & $100^{\mathrm{a}}$ \\
\hline T4 & 7.21 & 7.15 & 304 & $3080^{\mathrm{b}}$ & $2776^{\mathrm{b}}$ & $91.2^{\mathrm{c}}$ \\
\hline SEM & $\mathbf{0 . 5 2}$ & $\mathbf{0 . 2 6}$ & $\mathbf{7 6 . 3 1}$ & $\mathbf{5 8 . 3 4}$ & $\mathbf{4 1 . 3}$ & $\mathbf{2 3 . 1 1}$ \\
\hline P-value & $\mathbf{0 . 7 5 6}$ & $\mathbf{0 . 6 2 1}$ & $\mathbf{0 . 5 1 1}$ & $\mathbf{0 . 0 4}$ & $\mathbf{0 . 0 0 1 5}$ & $\mathbf{0 . 0 1}$ \\
\hline
\end{tabular}

a- c, Means within a row not sharing similar superscripts are significantly different.

$\mathrm{T} 1=$ basal diet contained $34 \mathrm{Kg} / 100 \mathrm{Kg}$ Berseem hay.

$\mathrm{T} 2=$ basal diet contained 10.75 Salix safsaf +23.25 Berseem hay $\mathrm{Kg} / 100 \mathrm{Kg}$.

T3=basal diet contained 17 Salix safsaf + 17 Berseem hay Kg/100 Kg.

T4 basal diet contained 23.25 Salix safsaf +10.75 Berseem hay Kg/100Kg. 
Means of pre- weaning survival rate $(\%)$ from birth to weaning age in the treatments groups were 94.6, 100, 100 and 95.2\%, respectively (Table 4). The differences between the treatments were significant $(\mathrm{P}=0.01)$.

\section{Economic evaluation:}

Average total body weight gain to weaned rabbits and feeding cost are generally among the most important factors involved in achievement of maximum efficiency values of meat production. The relative economic efficiency (REE) of the different formulated diets as affected by different treatments is shown in Table 5.

It should be pointed that the relative economic efficiency values were calculated according to the prevailing cost price of average weight gain of kits/ does rabbits.

Table (5): Economical efficiency as affected by dietary treatments to weaned rabbits.

\begin{tabular}{|l|c|c|c|c|}
\hline \multirow{2}{*}{ Items } & \multicolumn{4}{|c|}{ Treatment groups } \\
\cline { 2 - 5 } & T1 & T2 & T3 & T4 \\
\hline Average litter weight gain (Kg) & 2.58 & 3.07 & 3.04 & 2.78 \\
\hline Price of 1kg body weight & 38 & 38 & 38 & 38 \\
\hline $\begin{array}{l}\text { Selling price/average weight gain, (g) } \\
\text { (LE) (A) }\end{array}$ & 98.04 & 116.66 & 115.52 & 105.64 \\
\hline $\begin{array}{l}\text { Average total feed intake/ doe rabbit } \\
\text { (Kg) }\end{array}$ & 7.87 & 8.34 & 8.21 & 7.90 \\
\hline Price/kg feed(LE) & 4.9 & 4.7 & 4.5 & 4.3 \\
\hline Total feed cost/doe rabbit (LE) (B) & 38.56 & 39.2 & 36.95 & 33.97 \\
\hline Net revenue(LE) $^{1}$ & 59.48 & 77.46 & 78.57 & 71.67 \\
\hline Economic efficiency $^{2}$ & 1.54 & 1.98 & 2.13 & 2.11 \\
\hline Relative Econ. Eff. $^{3}$ & 100 & 129 & 138 & 137 \\
\hline
\end{tabular}

Ingredients prices (L.E. per ton) at 2018 were: 3400 barley; 4050 yellow corn; 2950 berseem hay $(12 \%)$; 3000 wheat bran ; 7850 soybean meal $(44 \%)$; 250 limestone ; 25000 premix ; 550000 DL-methionine ; 21000 DL-lysine; 10500 di-calcuim phosphate ; 500 Bean Straw; 500 salt; 1800 cane molasses. - Adding 100 L.E. /ton for pelleting.

(1) Net revenue $=\mathrm{A}-\mathrm{B}$.

(2) Economic efficiency $=(\mathrm{A}-\mathrm{B} / \mathrm{B})$.

(3) Relative Economic Efficiency= Economic efficiency of treatments other than the control/ Economic efficiency of the control group.

Results indicated that using Salix Safsaf as replacement of Berseem hay in doe rabbit diets improved slightly the net revenue and reduced the total feed cost.

The lowest total feed cost / doe rabbit (33.97 LE) was observed with doe rabbits fed the diet T4. Data showed that 50\% Salix Safsaf hay 
EFFECT OFREPLACEMENT Salix SafsafWITH BERSEEM HAY ON RABBITS 161

in Berseem hay diet to doe rabbit gave the best economic efficiency (2.13). The results indicated that $10.75,17$ and $23.25 \mathrm{Kg} / 100 \mathrm{Kg}$ Salix Safsaf hay as a partial replacement of Berseem hay improved the REE of diets by 129,138 and $137 \%$, respectively, when compared with the doe rabbits fed T1. While, the economic efficiency values were raised with Salix Safsaf hay in Berseem hay diets 28.6, 38.3 and $37 \%$, respectively, compared with rabbits fed the control diets. No available feasibility study about the cost of diets when Safsaf hay is partial replaced Berseem hay. In parallel to our results Oliveira et al (2011) and Alemede et al (2014) reported that feed cost per $\mathrm{kg}$ of body weight fed on diet containing $79.83 \%$ cassava byproduct had been reduced by $23.63 \%$ compared with the control diet.

Conclusion, Salix Safsaf hay can be considered as good source of principle compounds as Berseem hay. The results of the study revealed that all tested levels of Salix Safsaf hay were useful as a natural feed substitution with Berseem hay to maintain productive and could reduce the negative effects of feed cost for does rabbits.

\section{REFERENCE:}

Abdel-Kafy, E. M.; Sabra; Enayat, Z. A. M.; Abul-Azayem, H.; Manal M. Saudy and El-Aasar, T. A. (2017). Growth and Carcass Traits of Native Middle-Egypt Rabbits Fed Different Levels of Digestible Energy and Crude Protein Diets. J. Animal and Poultry Prod., Mansoura Univ., Vol.8 (8): 221-226.

Alemede, I.C.; Onyeji, E.A.; Tsado, D.B. and Shiawoya, E.L. (2014). Reproductive Response of Rabbit Does to Diets Containing Varying Levels of Horseradish (Moringa oleifera). Leaf Meal. Vol.4, No.19, 62-68.

AOAC (1996). Association of Official Analytical Chemists. Association of Official Analytical Chemists $16^{\text {th }}$ Edn., Gaithersburd, MD, USA.

Basyony, M.M.; Eman, I. Abd El Gawad and Dohreig, R.M.A.(2018). Evaluation of Egyptian Tree Willow (Salix Safsaf) Leaves And Its Feeding Affect on Productive Performance of New Zealand White Rabbits. Egyptian Journal of Rabbit Science, 28 (1): 39-62.

Bissett NG. (1994). Herbal drugs and phytopharmace uticals. Stuttgart: Med. Pharm CRC Press, 566. 
Blaxter, K.L. (1968): The Energy Metabolism of Ruminants. 2 Ed. Charles Thomas Publisher, Spring Field. Illinois, U.S.A.

Calsamiglia, S.; Stem, M.D. and Frinkins, J.L. (1995). Effects of protein source on nitrogen metabolism in continuous culture and intestinal digestion in vitro. J. Anim. Sci., 73: 1819.

Cheeke, P.R.; Patton, N.M. and Tempelton, G.S. (2013). Rabbit Production. ${ }^{\text {th }}$ Edition; Interstate, Danville IL., USA.

Chen, W.; Ohmiya, K.; Shimizu, S. and Kawakami, H., (1988). Isolation and characterization of an anaerobic dehydmvanillindegradins bacterium. Appl. Environ. Microbiol., 54:1254-1257.

Conrad, H.R. (1966). Symposium on factors influencing the voluntary intake of herbage by ruminants: physiological and physical factors limiting feed intake. J. Anim. Sci., 25:227-235.

De Blas, C. and Wiseman, J. (1998). The Nutrition Of The Rabbit. New York: CABI Publishing, 344p.

Duncan, D.B. (1955). Multiple Rang and Multiple F-Test. Biometrics, 11: $1-42$.

Ekambaram,B.; Prabhakar Rao, V.; Sreerama Murthy, A.; Satyanarayana, A.; and Ramesh Gupta, B.(2006). Genetic and non-genetic factors affecting the litter traits of broiler rabbits. Indian J. Anim. Res., 40(1): 9-14.

Etima, N.N. and Oguikeb, M.A. (2014). Lactation Stimulating and Growth Promoting Effects of Aspilia africana Fed to Rabbit Does. Russian Agricultural Sciences, 40( 5) : 385-389.

Fekete, S. and Gippert, T. (1986). Digestibility and nutritive value of nineteen important feedstuffs for rabbits. J. Appl. Rabbit Res., 9(3): 103-108.

Fotsch, G.; Pfeifer, S.; Bartoszek, M.; Franke, P. and Hiller, K. (1989). Biotransformation of phenolglycosides leiocarposide and salicin. Pharmazie; 44:555-8.

Goering, H.K. and Van Soest, P.J. (1970). Forge Fiber Analysis (Apparatus, Reagents, Procedure and Some Applications). Agriculture Hand Book 379, USDA, Washington and DC., USA.

Guevara-Escobar, A., (1999). Aspects of a willow pasture system related to pasture production in New Zealand. Ph.D, Thesis, Massey University, New Zealand.

Ibrahim Sh.A.M., El-Ghamry A.A., El-Mallah G.M. (2000). Effect of some medicinal plants of Labiatae family as feed additives on growth and metabolic changes of rabbits. Egyptian $J$ of Rabbit science Pages: Volume 10, Number 1; pp 105-120. 
EFFECT OF REPLACEMENT Salix SafsafWITH BERSEEM HAY ON RABBITS 163

Jiménez-Peralta, F.S.; Salem, A.Z.M.; Mejia, H.P.; González, R.M.; Albarrán, P.B.; Rojo, R.R.; Tinoco, J.L. (2011). Influence of individual and mixed extracts of two tree species on in vitro gas production kinetics of a high concentrate diet fed to growing lambs. Livest. Sci. 136:192-200.

Iyeghe-Erakpotobor, G.T.; Oyedipe, E.O.; Eduvie, L.O. and Ogwu, D. (2006). Nutrient digestibility of rabbit does in different stages of reproductive cycle under tropical conditions. Journal of Animal Physiology and Animal Nutrition, 91(1):74-82.

Julkunen-Tiitto R. and Meier B. (1992). The enzymatic decomposition of salicin and its derivatives obtained from Salicaceae species. Journal of Natural Products; 55:1204-12.

Jo Smith; Kaisa Kuoppala; David Yáñez-Ruiz; Katharine Leach and Marketta Rinne. (2014). Nutritional and fermentation quality of ensiled willow from an integrated feed and bioenergy agroforestry system in UK. Maataloustieteen Päivät .

Knight, P., Beard, A. and Wrathall, J. (1989). Evidence that the bovine ovary secretes large amounts of monomeric inhibin alpha subunit and its isolation from bovine follicular fluid. J. Mol. Endocrinol., 2:189-200.

Lise Manniche. (1989). An Ancient Egyptian Herbal, University of Texas Press, USA

Lukefahr, S.; Hohenboken, W.D.; Cheeke, P. R. and Paiton, N. M. (1983). Doe reproduction and preweaning litter performance of straightbred and crossbred rabbits. J. Anim. Sci., 57 (5): 10901099.

MacNitt, J.I. and Lukefahr, S.D. (1990). Effects of breed, parity, day of lactation, and number of kits on milk production of rabbits, $J$. Anim. Sci., 68: 1505-1512.

Mahmoud E.A.A. (2013). A study on Some Factors Affecting Milk Yield in New Zealand White Rabbits Under Egyptian Conditions. Benha Veterinary Medical Journal, Vol. 25, No. 2, Pp: 13 -22.

Makkar, H.P.S. (2003). Quantification of Tannins in Tree and Shrub Foliage. Kluwer Academic, Dordrecht, pp. 102.

McNitt, J.I. and Lukefahr S.D. (1990). Effect of breed, parity, day of lactation and number of kits on milk production of rabbits. $J$. Anim. Sci., 68: 1505-1512. 
McWilliam, E.L.; Barry, T.N.; Lopez-Villalobos, N.; Cameron, P.N.; Kemp, P.D. (2005). Effects of willow (Salix) versus poplar (Populus) supplementation on the reproductive performance of ewes grazing low quality drought pasture during mating. Animal Feed Science and Technology, 119; 69-86.

McWilliam, E.L.H. (2004). The Effect of Poplar (Populus spp.) and Willow (Salix spp.); Supplementation on the reproductive performance of ewes grazing low quality drought pasture during mating. Animal Feed Science and Technology, 115, 1-18.

Meier, B.; Julkunen-Tiitto, R.; Tahvanainen, J. and Sticher, O. (1988). Comparative high-performance liquid and gas-liquid chromatographic determination of phenolic glucosides in Salicaceae species. Journal of Chromatography, 442, 175-186.

Muklada, H.; Kleina, J.D.; Glasserb, T.A.; Dvasha, L.; Azaizehc, H.; Halabia, d. N.; Davidovich-Rikanatie, R.; Lewinsohne, E. and Landaua, S.Y. (2018). Initial evaluation of willow (Salix acmophylla) irrigated with treated wastewater as a fodder crop for dairy goats. Small Ruminant Research, Volume , 163, Pages 7683.

Oliveira, A.F.G.; Scapinello, C.; de Paula Leite, M.C.; Motta, A.C.M.; Figueira,J.L.; Catelan, F. and Retore,M. (2011). Evaluation of the reproductive performance of rabbits does fed a half-simplified diet based on cassava byproducts. Revista Brasileira de Zootecnia, $40 \quad$ (11): 2456-2461.

Pitta, D.W.; Barry, T.N.; López-Villalobos, N. and Kemp, P.D. (2007). Willow fodder blocks - an alternate forage to low quality pasture for mating ewes during drought. Animal Feed Science and Technology, 133: 240-258.

Rommers, J. M.; Meijerhof, R.; Noordhuizen, J. P. T. M. and Kemp, B. (2002): Relationships between body weight at first mating and subsequent body development, feed intake, and reproductive performance of rabbit does. J. Anim. Sci., 80:2036-2042.

Saha, B.K. , Sarker, M.B., Alam, M.H., Kabir, M.E., Amin, M.R. and Moniruzzaman, M. (2013): Effect of re-mating intervals on growth and reproductive performance of rabbits. Bang. J. Anim. Sci., 42 (2): 143- 147.

Saller, R., Melzer, J. and Felder, M. (2008): Pain relief with a proprietary extract of Willow bark in rheumatology. An Open Trial. Schweiz. Zschr. Ganzheits Medizin, 20: 156-162. 
EFFECT OF REPLACEMENT Salix SafsafWITH BERSEEM HAY ON RABBITS 165

Salem, A.Z.M., Kholif, A.E., Mona M.Y. Elghandour, Buendía, G., María D. Mariezcurrena, Hernandez, S.R. and Camacho, L.M. (2016): Influence of Oral Administration of Salix Babylonica Extract on Milk Production and Composition in Dairy Cows. Italian Journal of Animal Science; 13:2978.

Salem, A.Z.M., Olivares, M., López, S., González-Ronquillo, M., Rojo, R., Camacho, L.M., Cerrillo, S.M.A., Mejia, H.P., (2011): Effect of natural extracts of Salix babylonica and Leucaena leucocephala on nutrient digestibility and growth performance of lambs. Anim. Feed Sci. Tech., 170:27-34.

Salem, A.Z.M., Robinson, P.H., Lopez, S., Gohar, Y.M., Rojo, R. and Tinoco, J.L. (2010): Sensitivity of sheep intestinal lactic acid bacteria to secondary compounds extracted from Acacia saligna leaves. Anim. Feed Sci. Tech., 161:85-93.

SAS, (2001): SAS/STAT Software, Release 8.02. SAS Institute Inc. Cary, North Carolina.

ThiMui, N.; Dinh Van, B. and Ørskov, E.R. (2005). Effect of foliages containing condensed tannins and on gastrointestinal parasites. Animal Feed Science Technology, 121, 77-87.

Xiccato, G. (1996). Nutrition of Lactating Does. In: Proc. 6th World Rabbit Congress, Toulouse. 1:29-47.

Yamani, K.A.O.; Daader A.H. and Askar, A.A. (1992). Non genetic factors affecting rabbit production in Egypt. Options Mediterraneennes: Seri Seminaries.17: 159-172. 


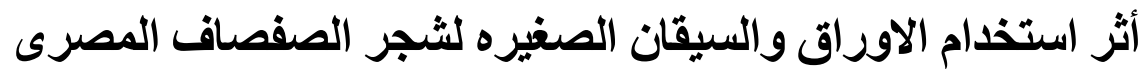
فى علائق امهات الارانب على الأداء التناسلى.

محمد بسيونى محمد محمود1، ايمان اسماعيل عبد الجواد², رجب محمد عبد المنع33

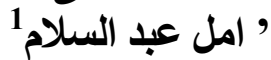

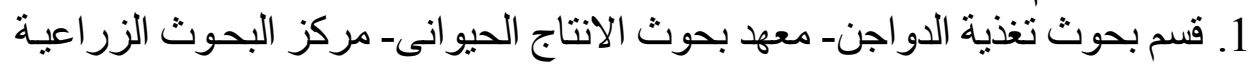

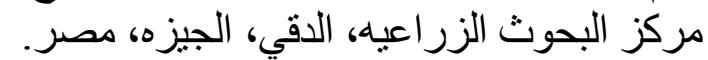

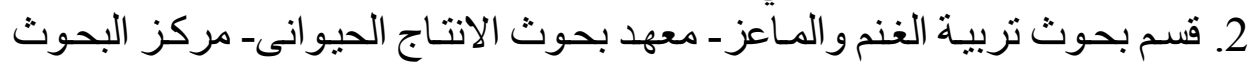

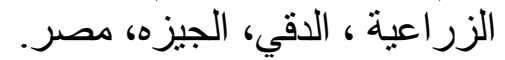
3. معهد بحوث التناسليات، مركز البحوث الزر اعيه، الدقي، الجيزه، مصر.

أجريت هذة التجربة لدراسة تأثير إستخدام 25 و50 و75\% من اوراق وسيقان

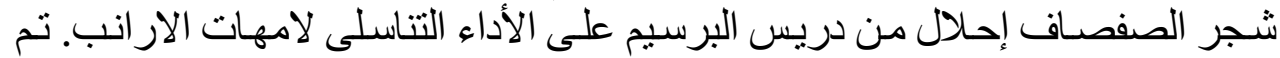

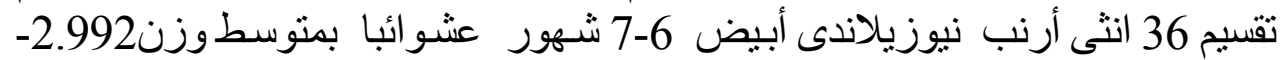

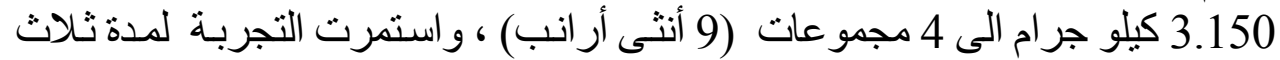

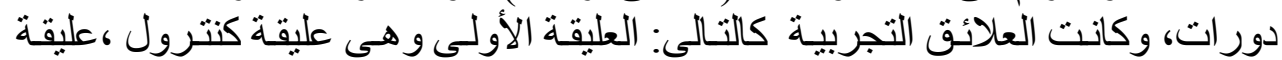

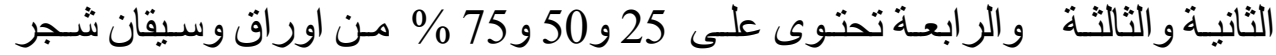

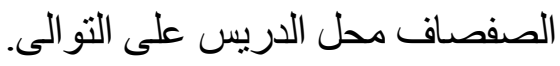

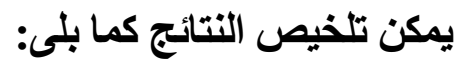

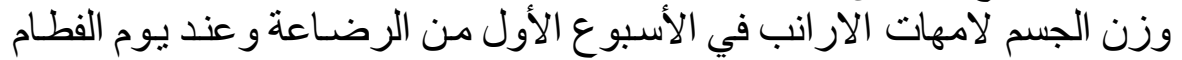

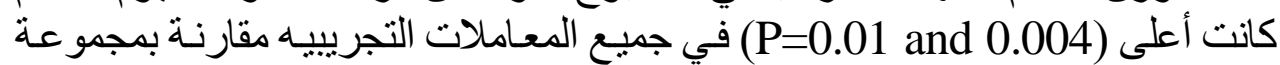

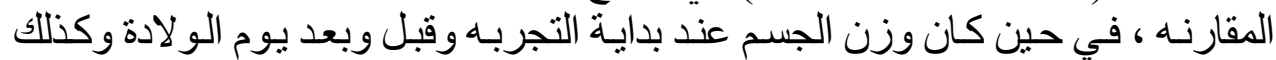

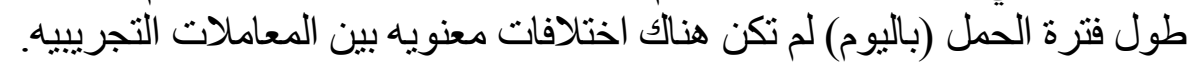

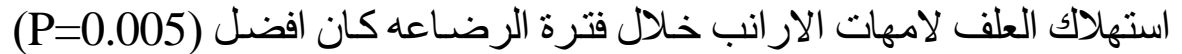

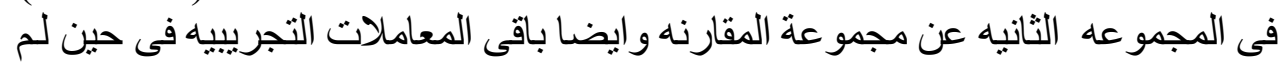

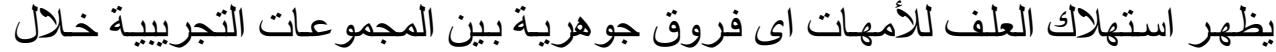

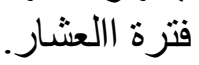
انتاج اللبن خـال فترة الرضـاعه لامهات الار انب في الاسبوع الثانى و الثالث

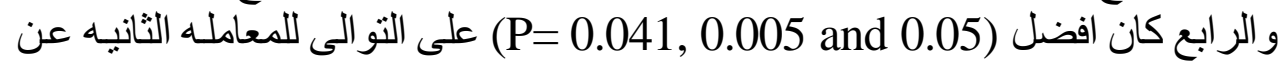
المجمو عه المقارنه وباقى المجاميع التجريبيا. 
EFFECT OF REPLACEMENT Salix SafsafWITH BERSEEM HAY ON RABBITS 167

متوسط وزن الخلفات عند الفطـام و الزيـاده فـى وزن الجسم للخلفـات المفطومـهـ

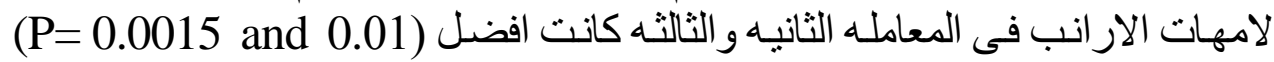

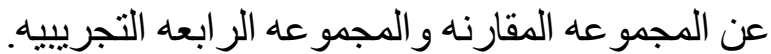

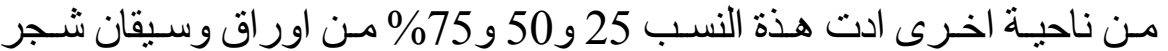

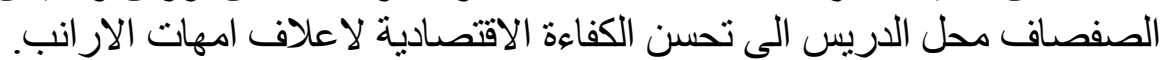

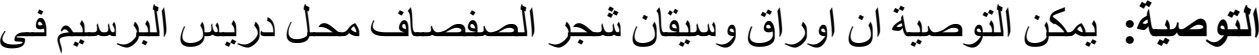

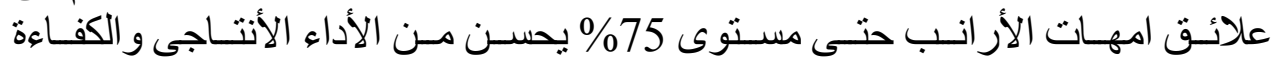
الأقتصادية لانتاج الار انب. 